Andrii Bakai', Dmytro Kupriienko ${ }^{2}$

\title{
IMPROVEMENT OF THE ORGANIZATIONAL AND LEGAL MECHANISM OF MEDICAL SUPPORT OF THE SECURITY AND DEFENSE SECTOR OF UKRAINE IN CRISES BASED ON NATO STANDARDS
}

Keywords: integrated medical space of troops (forces), interoperability, integrated treatment system, capability-based planning, principles and policy of health service support, military medicine reform, level system of medical support, control structure.

ABSTRACT: The article has considered the general principles and capabilities of the medical support of NATO troops, confirmed the expediency of further transformation of tasks and functions of the state in terms of medical support of troops (forces) of the security and defense sector of Ukraine in crises through the approximation to the relevant NATO standards, justified the need to implement the Euro-Atlantic experience of rendering medical care, use the general framework of categories and concepts, principles of the evaluation of capabilities (assets) of medical support which will contribute to the development of integrated medical space for medical defense of troops (forces) and elaboration of individual crisis response model taking into account the basic international requirements. The authors have determined the priority tasks of further cooperation between Ukraine and the North Atlantic Treaty Organization in the context of the reforms of medical logistics. It has been substantiated the need to keep reforming milita-

${ }^{1}$ Head of the Bureau of Planning and Medical Supply of the Health Office at the Human Resources Department, Administration of the State Border Guard Service of Ukraine, abakay@dpsu.gov.ua; a.e.bakai@ukr.net. ORCID: 0000-0001-8752-2159.

2 Doctor of Military Sciences, Deputy Head (Deputy Dean) for Educational and Methodological Work of the Faculty of Management Training, National Academy of the State Border Guard Service of Ukraine named after Bohdan Khmelnytskyi, dakupriyenko@nadps.dpsu; kupriyenko@ukr.net. ORCID: 0000-0002-4086-1310. 
ry medicine in conformity with NATO standards and recommendations that will promote an active involvement of medical services of troops (forces) in medical support of national and multi-domestic contingents during crises and adaptation of interoperable medical capabilities of joint missions under the auspices of NATO and the UN. The research has analyzed the mechanisms of interdepartmental coordination on medical support of troops (forces) and proved the feasibility of using the experience of NATO member states in the organization and functioning of the system of medical support of the military contingent with the adaptation of NATO doctrinal documents to the realities of modern Ukraine.

The authors have justified that the need to substantiate the personnel, provision, training, maintenance procedure of medical units and medical strengthening groups is gaining currency in the medical support system of troops (forces) to secure the early specialized medical care to injured during the first day after injury (lesion) at inpatient facilities deployed on the evacuation routes.

The research finding has resulted in the development of fundamentals for improvement of the organizational-legal mechanism of the security and defense sector of Ukraine during crises to approximate to NATO standards, principles and policy of health service support of troops. It is based on the cyclical process, which begins with stating a problem, organization of the enforcement and control system.

Consequently, the fulfillment of tasks on the improvement of the organizational and legal mechanism of medical support of the security and defense sector of Ukraine during crises relying on NATO standards will have a synergetic effect.

Implementation in Ukraine of successful NATO practices in health service support during crises will allow approximating state capabilities to the basic international requirements.

\section{INTRODUCTION}

Ukraine's non-aligned status didn't provide it with the complete defense against external aggression. International guarantees of independence, sovereignty and inviolability of borders proved to be insufficient. Thus, 
the need for sweeping changes in the state policy - primarily, in the realm of national security and defense - arose.

Therefore, on February 7,2019, the Constitution of Ukraine was amended in terms of the determination of the strategic course of the state on acquiring full-fledged membership of Ukraine in the European Union and in the North Atlantic Treaty Organization (hereinafter referred to as "NATO"). In the context of European and Euro-Atlantic integration, it is essential to conduct a complex of reforms of pivotal life spheres of Ukraine for their beforehand preparation and adaptation to European and North Atlantic policies, standards, principles, law rules and administrative approaches.

Under the framework of the implementation of Davos obligations of Ukraine and one of the major priorities and indicators of the system reform of the security and defense sector of Ukraine (hereinafter referred to as "SDSU") is the attainment of compliance with the international institutional and administrative-logistical criteria necessary for membership in the above organizations and ensuring interoperability of the military sector with NATO member states.

The Annual National Program under the auspices of the NATOUkraine Commission for 2020 declares the enhancement of the processes aimed at meeting NATO membership criteria by accelerating domestic reforms, transition of the security and defense sector of Ukraine to NATO standards and the improvement of interoperability, harmonization of the legislation of Ukraine with one of NATO member states in the area of security and defense of the Ukrainian Armed Forces units with NATO armies (Ukaz Prezydenta Ukrainy, No. 203/2020).

The authors have highlighted two aspects among the core objectives of reforms, which are necessary conditions for Ukraine's NATO membership: 1) strengthening of the state defense capacity (through the optimization of the security and defense sector of Ukraine); 2) meeting the relevant criteria of interoperability on logistics (including medical).

The legislation provides the internal policy of Ukraine focuses on the protection and security of citizens (Ukaz Prezydenta Ukrainy, No. 392/2020). Moreover, civic health, including military personnel, is an essential component and a resource of the national security (The Cabinet of Ministers of Ukraine, 2018). 
Thus, one of the topical issues, which has the pragmatic relevance in the context of the abovementioned and the article is devoted to, is the advancement of the medical support system of the SDSU in crises.

In order to determine a strategy and primary development areas of medical support of the SDSU in crisis situations, the Cabinet of Ministers of Ukraine approved the Military Medical Doctrine of Ukraine (The Cabinet of Ministers of Ukraine, 2018), which declared the implementation of the international standards, principles and medical support policy of NATO by taking into account their requirements in the legislation on servicemen health status, forming the necessary structure and strength of medical services and maintaining medical support. At the same time, the involvement of advisory, practical and logistical assistance for targeted program reform of the departmental health care sector is one of the goals of practical cooperation between Ukraine and NATO.

Indeed, the necessity for carrying out activities on the organization of health support of the SDSU in crises determines an urgent need to create a unified medical space based on a peacetime health care system, which is restructured and strengthened to work in specific conditions, in particular, with a possible use of doctrinal recommendations, guidelines for monitoring healthcare, standards and evaluation procedures of NATO member states (Serdiuk, 2016).

In addition, in the course of reforming the system of military and civil medicine at the modern stage of Ukraine, it is essential to consider the need to build the interagency medical support system of the defense forces, which can contribute to the interoperable medical capabilities when conducting joint missions with NATO that prescribed by the law.

Planning and organization of medical support of the SDSU in crises should meet the Military Doctrine of Ukraine which provides for the eruption of modern military conflicts different in scale and nature: regional and local wars, armed conflicts (NATO Standardization Agreement).

According to the authors, it is important to take into account the mentioned preconditions when developing the national model of emergency response, the medical support system of the SDSU in crisis situations. 
Therefore, the purpose of the article is to do the groundwork for improving the organizational and legal mechanism of medical support of the security and defense sector of Ukraine in crises to approximate to standards, principles and policy of health service support of NATO troops.

To achieve the article's goal, some tasks have been solved:

- special aspects of the medical support of troops (forces) of the SDSU in the modern context have been identified;

- the modular approach to the medical support of NATO and SDSU troops has been analyzed;

- features of the medical support of NATO operations have been specified;

- directions for the improvement of the organizational and legal mechanism of medical support of the security and defense sector of Ukraine in crises situations have been substantiated.

\section{THEORETICAL BACKGROUND}

In general, the analysis of subject-related domestic and foreign literature sources allows the authors to state that the issues of medical support of the SDSU are of practical and theoretical relevance and extensively discussed under present-day conditions of Ukraine. The majority of scientific contributions deal with the analysis of the experience of civilmilitary cooperation to NATO standards as an integral part and a critical tool of crisis management during international peacekeeping and security operations under the auspices of NATO and the UN.

The papers of L.P. Antonenko, M.I. Badiuk, A.V. Barovska, N.V. Vasiukova, O.I. Vorobieva, A.M. Halushko, H.D. Kyrzhner, P.V. Klimenko, D.V. Kovyda, V.O. Kozachok, R.M. Lyman, I.A. Lurin, O.O. Liashenko, O.V. Mazurenko, O.O. Mykyta, O.M. Mylchenko, O.Z. Nabochenko, O.O. Olifirov, V.M. Pivnyk, M.M. Ryhan, H.H. Roshchin, S.M. Salkutsan, A.M. Serdiuk, I.K. Sereda, Yu. M. Skaletskyi, V.V. Stebliuk, V.M. Tarasov, S.A. Tishchevskyi, V.V. Khmil, O.H. Shekera (Badiuk, Kovyda, Mykyta, 2016; Badiuk, Pivnyk, Liashenko, 2018; Serdiuk, 2016; Tarasov, Salkutsan, Mylchenko, 2016; Shekera, Stebliuk, Kyrzhner, 2014) covered the imple- 
mentation of standards, principles and policy of medical support of NATO troops in the medical support system of the SDSU in the context of peacetime and a special period.

The research by Zhakhovskyi V.O. is devoted to the improvement of the mechanism of public management of the human resources system of the medical service of the Armed Forces of Ukraine in terms of its European and Euro-Atlantic integration and substantiation of the concept of optimization of this system given Ukraine's approximation to NATO (Zhakhovskyi, 2014).

The authors have considered the development of the medical support system of law enforcement agencies of Ukraine amid its European and Euro-Atlantic integration (Bakai, Kupriienko, 2020).

In addition, in the authors' opinion, issues of evidence-based determination of further topical directions of the military medicine reform in Ukraine in conformity with NATO approaches remains poorly researched despite their fundamental practical relevance.

\section{NATO MEDICAL SUPPORT POLICY}

A military cooperation of Ukraine with NATO member states is considered as a critical part of the partnership as a whole. Implementation of NATO standards and procedures through the partnership during emergency response facilitates the accomplishment of Ukraine's strategic goal of Euro-Atlantic integration. An interest in the experience of military medical services of the foreign armies and, primarily, in the medical support of NATO armed forces has heightened. The issues of implementation of best practices in different aspects of military medicine are of vital importance for Ukraine, the territories of which have been temporarily annexed and an armed conflict has been going on for six years in the east.

In modern Ukraine, the key shortcomings of the organization of medical support of troops (forces), as a system of organizational and managerial measures and their realization in crises, compose a lack of unified approaches, uniform norms, guidelines, standards and principles of medical care delivery. 
American model of organization of medical support in crises has a conceptual and doctrinal nature compared to Ukrainian. There are several types of the doctrines: United States Army Doctrine; Allied Joint Doctrine, Doctrine of Multinational Forces (NATO and other states). The capstone document regulating the issues of medical support in the US is the Military Medical Doctrine. Multinational doctrines ensure unification, standardization and take into account the specifics of national military health systems. Provisions of the allied or partner doctrines are formulated in such a way so that the national priorities in medical support of individual member states don't interfere with interaction and cooperation.

Much attention is devoted to the aspect of medical support that was reflected in the Alliances Strategic Concept, 29 Apr. 1999, and MC Directive for Military Implementation of Alliance Strategy, 14 Jun. 1996. MC Directive 319 "NATO Principles and Policies for Logistics" notes that general principles of logistics usually belong to medical support of forces (NATO, Euro-Atlantic Partnership Council).

It should be emphasized that the new US defense strategy provides for a redistribution of forces at the system level. In other words, the adaptation of NATO bodies and control system is carried out through the general conceptual framework and principles of assessing the relevant forces and means used for the fulfillment of the assigned tasks.

NATO operations under special (extreme) conditions led to the further development of medical support. At present, NATO military medicine uses the most effective practices based on fundamental training (planning) and real-life experience and lessons learned from frequent military conflicts. This allows the medical system to adjust to the challenges caused by the quantitative and qualitative characteristics of victims, extreme environmental conditions, logistical bottlenecks and the fact that the need to complete a mission may precede medical needs (American College of Surgeons, 2006).

It is worth highlighting that NATO military medical unit requires a set of harmonized standards to function as a single organism. These standards should be included in a memorandum of understanding, a technical agreement and (or) implementation agreement between member states. Integration of national procedures and training courses into a multina- 
tional work environment is time consuming. Thus, certification should be two-stage. The first stage is the national certification of personnel or elements which will become a part of the military medical unit. The second one is the integration and certification of the national elements of the military medical unit.

At the same time, the control emphasis is on validation and certification of the functional responsibilities. States are recommended to use NATO Standardization Agreement (STANAG 2560 Evaluation of NATO Medical Treatment Facilities) for the national assessment and certification (NATO Standardization Agreement). Control over NATO medical treatment facilities consists of Medical Evaluation Manual (AMedP-1.6), Capability Matrix (AMedP-1.7) and Skills Matrix (AMedP-1.8). The functional responsibilities of medical support of operations are brought in line with each task and based on the modular approach. Many states prefer to use modules (or individual specialists) in the multinational medical functionality. The evaluation procedure should confirm the quality of care provided by the integrated health care system and identify potential risks. The procedure allows assessing the medical environment as part of NATO response forces. Thus, during the evaluation, the focus is on the effectiveness of medical forces against imposed requirements (Directive MC 326 "Medical Support Precepts and Guidance for NATO").

Military cooperation with NATO is deemed to be an essential element of Ukraine's partnership with this organization as a whole. The reform and military cooperation contribute to the Ukrainian strategic goal of EuroAtlantic integration through the gradual adoption of NATO standards and procedures, as well as the enhancement of interoperability between the Armed Forces of Ukraine and NATO, in particular, through the implementation of partnership goals and crisis response under the aegis of NATO (Ukaz Prezydenta Ukrainy, No. 5/2015).

In this regard, interest in the experience of military medical services of foreign armies and, above all, in the medical support of NATO forces has sparked. While contacting military medical services of foreign countries, it is important not to copy mechanically but to analyze, generalize and assess their experience critically. Its use should be balanced, selective and 
take into account specifics of the national SDSU and their medical support as well as real economic and logistic capabilities of the state.

The latest available revision of NATO provisions on the principles and policy of medical support states that the spheres of military and civil health care are the most related components of the civil-military interaction. Moreover, NATO always has the highest regard for the participation of military units in the recovery of natural and man-made emergencies. The very military medicine units can deploy special infrastructures and medical resources with autonomous support within a short time under adversity.

The readiness of medical services for their intended use in international peacekeeping operations and other joint actions, in which the Ukrainian peacekeeping contingent begins to participate, is ensured by achieving a core interoperability of the relevant structures of multinational formations through the application of common criteria, standards and principles of medical care that enshrines common approaches to planning, organization and procedure for providing medical care (medical protection) in crises and cooperation arrangements on efficient use of available medical resources, i.e. a balanced system of organizational and managerial measures and their implementation, etc.

In fact, it means that in the current context, the primary goal of military medicine reform in Ukraine should be the creation of a system of medical support for troops (forces), which is interoperable in terms of medical capabilities in the joint missions with NATO, and the introduction of modern technologies for the provision of medical care and treatment of wounded (injured) under the standards of medical care, clinical protocols and other industry standards in the health sector of NATO member states.

Integration of the system of medical support of troops (forces) into a united medical space of Ukraine includes interoperability of assets of medical services of the SDSU and civilian healthcare system for the fullblast implementation of their capabilities towards effective medical support of military personnel along with preservation of the organizational independence of medical services of the SDSU. The fundamental requirement for the organizational formation of medical services is the unification of the institutional structure, mobility and the modular principle, 
which ensures the interoperability of their specific elements and facilitates to advance survivability (sustainability) of the health care system.

The core elements of interoperability of medical services of the Defense Forces of Ukraine and NATO troops are the application of fundamental principles of medical support and common approaches to their organizational construction, maintenance of constant readiness of medical services to perform assigned tasks and their mobility of using a single complete standard equipment, the same requirements for military medical training (tactical medicine training of military servicemen), training of medical personnel and organization of protection of medical units and military treatment facilities.

The medical support system of troops (forces) is based on health agencies, which consist of medical units of military units and military treatment facilities (mobile and immobile). A number of these bodies in the medical support system is determined by the structure, strength, dislocation and use of troops (forces) and the need to guarantee the provision of well-timed and effective medical care. Assets of the medical service (levels of medical support) deployed on the evacuation routes are formed from specific functional components (Allied Joint Medical Support Doctrine), which are shown in Fig. 1.

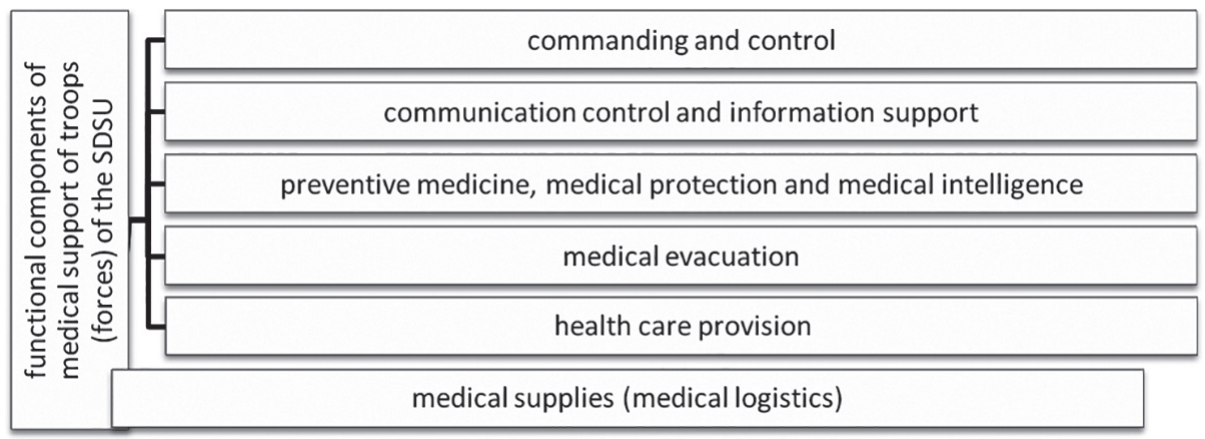

Fig. 1. Functional components of medical support of troops (forces) of the SDSU 


\section{SPECIAL ASPECTS OF MEDICAL SUPPORT OF TROOPS (FORCES) OF THE SDSU IN THE MODERN CONTEXT}

Modern nature of the use of troops (forces) provides for possible conducting large-scale military operations, which may be accompanied by a large number of sanitary losses both among military servicemen and civilians. Under such conditions, the following needs will additionally affect the activities of the military medical services:

- to involve civilian health facilities, some of which may be destroyed, to provide servicemen with medical care;

- to provide the civilian population with medical care by military medical services;

- to involve additional military transport for medical evacuation of the wounded and sick.

Medical support of troops (forces), which participate in the implementation of measures of the legal regime of state of emergency, martial law and (or) recovery of natural and man-made emergencies (crisis situations), is carried out under the requirements of legislative and statutory acts as well as governing documents prescribing the procedure of participation of troops (forces) in the mentioned actions. In such cases, medical support of troops (forces) includes measures for preventing or reducing the degree of injury of military personnel, timely provision of medical care for victims at the pre-hospital and hospital stages, their evacuation and treatment.

Consequently, a range of factors shown in Fig. 2 may affect the organization of medical support of troops (forces) of the SDSU. 


\begin{tabular}{|c|c|}
\hline \multirow{8}{*}{ 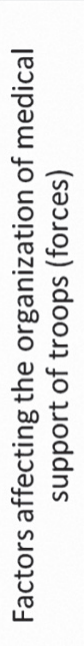 } & availability of departmental treatment facilities at the operational zone \\
\hline & a degree of the devlopemnt of the system of medical and evacuation support \\
\hline & $\begin{array}{l}\text { relocation of medical units and mobile military medical facilities (medical } \\
\text { reinforcement groups) in accordance with operation phases }\end{array}$ \\
\hline & holding of the wounded and sick at the stages of medical evacuation \\
\hline & a threat of capture of the deployed stages of medical evacuation by the enemy \\
\hline & $\begin{array}{l}\text { a capability of the forward stages of medical evacuation to provide medical care } \\
\text { in different conditions of the operational and medical environment with } \\
\text { subsequent medical evacuation to the relevant level of medical care (medical } \\
\text { evacuation stage) }\end{array}$ \\
\hline & $\begin{array}{l}\text { the availability and a sufficient numb } \\
\text { including }\end{array}$ \\
\hline & $\begin{array}{l}\text { interoperability with military medical services of other units of the SDSU and the } \\
\text { system of civialian healthcare }\end{array}$ \\
\hline
\end{tabular}

Fig. 2. Factors affecting the organization of medical support of troops (forces) of the SDSU

\section{MODULAR APPROACH TO MEDICAL SUPPORT OF THE TROOPS OF NATO AND SDSU}

In the context of building Smart Defense and implementation of the project "Pooling and Sharing of Multinational Medical Treatment Facilities", the modular approach to medical support is a key element of NATO plan to improve interoperability of national resources that will contribute to the creation of advanced medical capabilities under NATO (Allied Joint Medical Support Doctrine). It is based on the early formation of standardized functional units (modules), meeting particularities of tasks and operational requirements, which consist of the required number of staff of a certain level of training and qualifications, equipment and consumables. Types and a number of modules, which identify medical capacity, are adjusted to the operational medical environment. The modules are combined in such a way that together they create the necessary medical unit or military treatment facility. 
Therefore, application of the modular approach to the building of the medical support system of the SDSU at the national level will facilitate the more effective management of medical resources, in particular, through:

- the maintenance of organizational formation of medical units based on individual modules of capabilities, each of which has standard functions;

- the improvement of capabilities of the units of medical support and military treatment facilities at all levels of medical support;

- the assurance of compatibility of medical services of troops (forces) between each other and with civilian medical resources, as well as with medical services of NATO armed forces;

- the strengthening of medical capacity of troops (forces) by means of others without violating organizational and staff structure. At the same time, this keeps sufficient autonomy, integrity and functional capacity of each individual module (Conceptual Basis for a Modular Approach to Medical Support Capability).

The application of the mentioned approach to the formation of medical units is enormously important for medical unites and healthcare facilities of the second and third level.

\section{SPECIAL ASPECTS OF THE MEDICAL SUPPORT OF NATO OPERATIONS}

As envisaged in the Allied Joint Doctrine for medical support (AJP4.10), a range of capabilities of health service support and its scope must correspond to the tasks, quantitative and qualitative indicators of the armed forces and the threats which these forces face or may face. They must be adaptable to the changes or specific risks associated with the execution of tasks and allow working in conditions when the number of injured exceeds the expected daily number. Capabilities of health service support, regardless of whether they were deployed in full or partially, must together compose a system of health service support according to the following features (Allied Joint Medical Support Doctrine): 
to work as a network of subsystems of a single system, which can provide a higher level of medical care due to the synergistic effect than under advancing capacity of each specific part;

to consist of flexible components the configuration of which is easy alterable to perform many tasks (in the context of different roles) in crises;

to be in line with the rational balance between clinical needs and a tactical situation;

to ensure multi-level gradual clinical capabilities which meet the needs of patients in terms of both temporal and spatial requirements;

to combine maritime, land and air medical capabilities if necessary.

Functions and capabilities of the military healthcare system of NATO, which are necessary for military health support of troops, are specified by well-defined roles. Minimum capabilities of every preceding role should be similarly kept in the following roles (Table 1).

Table 1. Characteristics of the roles of military health care of NATO

\begin{tabular}{|l|l|}
\hline Role & Role characteristics \\
\hline Role 1 & $\begin{array}{l}\text { It encompasses a set of primary health care capabilities which includes triage, } \\
\text { pre-hospital emergency care and essential diagnostics. }\end{array}$ \\
\hline Role 2 & $\begin{array}{l}\text { It encompasses a set of military health care capabilities which enhances the resu- } \\
\text { scitative spectrum of the role } 1 \text { by capabilities essential to preserve life, limb, and } \\
\text { function and stabilize the patients' condition for further transport and treatment }\end{array}$ \\
\hline $\begin{array}{l}\text { Role 2 } \\
\text { forward }\end{array}$ & $\begin{array}{l}\text { It provides high mobility, deployment in austere or unsecure tactical environ- } \\
\text { ments enabling forward projected resuscitative and surgical treatment to control } \\
\text { bleeding, maintain circulation, restore perfusion and preserve life, limb, and func- } \\
\text { tion. R2F capabilities may also be deployed to augment or to enhance other medi- } \\
\text { cal capabilities in theatre. R2F capabilities comprise triage, essential diagnostics, } \\
\text { damage control resuscitation and damage control surgery. Their resources are } \\
\text { limited. R2F capabilities rely on immediate medical evacuation and resupply after } \\
\text { treatment. }\end{array}$ \\
\hline $\begin{array}{l}\text { Role 2 } \\
\text { basic }\end{array}$ & $\begin{array}{l}\text { It preserves life, limb, and function due to resuscitative and surgical interventions. } \\
\text { R2B capabilities may operate highly mobile, afloat or land; they are based and } \\
\text { comprise triage, essential diagnostics, damage control resuscitation and damage } \\
\text { control surgery, short term post-operative critical care, limited patient holding and } \\
\text { medical supply. R2B capabilities may also be deployed to augment or to enhance } \\
\text { other medical capabilities in theatre. }\end{array}$ \\
\hline
\end{tabular}




\begin{tabular}{|l|l|}
\hline Role & Role characteristics \\
\hline $\begin{array}{l}\text { Role 2 } \\
\text { enhan- } \\
\text { ced }\end{array}$ & $\begin{array}{l}\text { Role } 2 \text { enhanced (R2E) capabilities may provide diagnostic, specialist and hospi- } \\
\text { tal care essential to stabilize and prepare patients for strategic evacuation. In addi- } \\
\text { tion to the capabilities of a role } 2 \text { basic, this includes but is not limited to surgery, } \\
\text { x-ray, laboratory, blood bank, pharmacy and sterilization. }\end{array}$ \\
\hline Role 3 & $\begin{array}{l}\text { The role } 3 \text { comprises a set of deployable specialist and hospital care capabilities } \\
\text { which at least includes computed tomography and oxygen production in addition } \\
\text { to all the R2 capabilities listed above. R3 capabilities may reduce the need for } \\
\text { a repatriation of patients and enable a higher standard of care prior to strategic } \\
\text { evacuation. }\end{array}$ \\
\hline Role 4 & $\begin{array}{l}\text { The role } 4 \text { comprises the full spectrum of military health care including highly } \\
\text { specialized capabilities (s reconstructive-surgery, prosthetics and rehabilitation) } \\
\text { that cannot be deployed or will be too time consuming to be conducted in theatre. } \\
\text { Role } 4 \text { medical support is a national responsibility and normally provided by (mi- } \\
\text { litary or military contracted civilian) hospitals in the casualty's country of origin } \\
\text { or at a regional hub (firm base). }\end{array}$ \\
\hline
\end{tabular}

\section{IMPROVEMENT OF THE ORGANIZATIONAL AND LEGAL MECHANISM OF MEDICAL SUPPORT OF THE SECURITY AND DEFENSE SECTOR OF UKRAINE IN CRISES}

Taking into account the abovementioned, the authors put forward an approach to improve the organizational and legal mechanism of medical support of the SDSU in crises. The approach's essence involves adapting Allied Joint Doctrine for Medical Support AJP-4.10 (STANAG 2228) in terms of the division of medical support system of troops (forces) into the defined stages and development of medical capabilities meeting the roles (norms and rules) of medical support by NATO standards, namely:

- role 1 - to secure the provision of a specific set of primary health care capabilities and pre-hospital emergency care;

- role 2 - to secure a high mobility of medical care (through deploying field mobile hospital and functioning of mobile units (mobile diagnostic and treatment complexes and military medical clinical centers), and stabilization of the patients' condition during the forward and tactical medical (air medical) evacuation; 
- role 3 - to secure top standards of health care (qualified with the elements of specialized) before conducting strategic medical (aeromedical) evacuation through combining capabilities of special and hospital aid (incl. in deployable ones) (hospitals, regional military medical clinical centers);

- role 4 - to secure a tertiary care (Main Military Medical Clinical Center, clinical health centers, medical rehabilitation centers).

A reasoned outcome of the implementation of the above roles is primary tasks of the organization of interagency cooperation in the context of effective medical support of troops (forces) during crises, as follows:

1) to advance the stage system of health care where the next stage includes capabilities of the previous one and amplifies them;

2) to combine and develop joint immobile and mobile capabilities for health care.

In turn, it will make it possible:

- to provide a higher level of medical care (than under adding medical functional capabilities);

- to adhere to the principle of flexible components the configuration of which is easy alterable to perform many tasks (in the context of different roles) under any operational medical environment and tactical situation;

- to combine maritime, land and air medical capabilities efficiently.

Moreover, in the medium term, new opportunities become available to achieve the following goals:

1) to create a multilevel system of medical support (a system of medical evacuation measures with care by echelon) which can apply medical capabilities (resources and possibilities) to the establishments of different management levels, in various localities and provide medical care to the wounded (sick) in the shortest possible time and the fullest extent, taking into account the available forces and means and capabilities of medical and aeromedical evacuation without violating continuousness of medical care;

2) to approve the fundamental division of the medical support system into well-defined stages and to kick off the process of building medical capabilities following NATO norms and rules of medical support; 
3) to implement the modular approach in the organizations of medical support that will ensure the advancement of interoperability of medical capabilities;

4) to accomplish compatibility of the system of medical support of troops (forces) with a system of health service support of NATO state members with acquisition of adaptive capacity to changes or specific risks;

5) to accomplish NATO-Ukraine Partnership Goal (G5404) "On the Reform of Military Medical System";

6) to build a level health care system.

\section{CONCLUSIONS}

Consequently, having relied on the analysis of the statutory framework of medical support of NATO state members, the article has outlined the principal directions for improving the organizational and legal mechanism of medical support of the SDSU in crises.

The authors have proved the expediency of implementing the advanced model of a multilevel system of medical support of troops (forces) with an option of applying medical capabilities to the establishments of different management levels in the general system of an integrated medical space.

It has been substantiated managerial aspects of the organization of multilevel system of medical support (the system of treatment evacuation measures with care by echelon), which is based on the fundamental division of medical support system into four stages, and the need to initiate the formation of medical capabilities in complying with the roles of NATO medical support. This is aimed at achieving compatibility of the medical support system of troops (forces) of the SDSU with health service support of NATO member states.

The implementation of standards, principles, policy and doctrinal fundamentals of health service support of NATO into the domestic practice has to take into account the national peculiarities of health service support in Ukraine. 
The sphere of standardization and codification in the system of medical support of troops (forces) needs elaborating and statutory consolidating.

Adjustment of the experience of NATO bodies and management system should be carried out using general conceptual framework and principles for the assessment of necessary assets involved to fulfill the assigned tasks.

Thus, the performance of tasks of improving the organizational and legal mechanism of medical support of the SDSU in crises based on NATO standards will have a synergetic effect.

The introduction in Ukraine of positive experience in the organization of NATO health service support in crises will approximate the state's capabilities to basic international requirements.

\section{BIBLIOGRAPHY:}

AJP-4.1O (A). Allied Joint Medical Support Doctrine. Retrieved from: https://shape.nato. int/resources/site6362/medica-secure/publications/ajp-4.10(a).pdf.

American College of Surgeons. Resources for Optimal Care of the Injured Patient, 2006. Chicago, IL: ACS; 2007. Retrieved from: http://usaisr.amedd.army.mil/cpgs.html.

Badiuk, M.I., Kovyda, D.V., Mykyta, O.O. (2016). Dorozhnia karta rozrobky normatyvnoi bazy medychnoho zabezpechennia Syl Oborony Ukrainy v umovakh oboronnoi reform [Road map for the development of statutory framework of medical support of the Defense Forces of Ukraine in the context of the defense reform]. Military medicine of Ukraine, vol. 16, no. 4, pp. 5-12. Retrieved from: http://nbuv.gov.ua/UJRN/ vmuk_2016_16_4_3.

Badiuk, M.I., Pivnyk, V.M., Liashenko, O.O. et al. (2018). Udoskonalennia orhanizatsii medychnoho zabezpechennia pidrozdiliv terytorialnoi oborony Ukrainy [Improvement of the organization of medical support of the territorial defense units of ]. Military medicine of Ukraine, vol. 18, no. 3, pp. 100-104. Retrieved from: http://nbuv. gov.ua/UJRN/vmuk_2018_18_3_19.

Bakai, A.Ye., Kupriienko, D.A. (2020). Rozvytok systemy medychnoho zabezpechennia syl okhorony pravoporiadku Ukrainy v konteksti yii yevropeiskoi ta yevroatlantychnoi intehratsii [Development of the medical security system of law enforcement forces of Ukraine in the context of its European and Euro-Atlantic integration]. 
Investments: practice and experience, no. 1, pp. 134-141. Retrieved from: http://www. investplan.com.ua/pdf/1_2020/24.pdf.

"Conceptual Basis for a Modular Approach to Medical Support Capability". Appendix 2 to IMSM-0289-2012 dated 18 July, 2012.

NATO, Euro-Atlantic Partnership Council. Pryntsypy i polityka medychnoho zabezpechennia NATO [NATO principles and policy of medical support]. Retrieved from: http://usaisr.amedd.army.mil/cpgs.html.http://milmed.org.ua/Publications /3_1NATO.doc.

NATO Standardization Agreement (STANAG 2560 Evaluation of NATO Medical Treatment Facilities).

Ukaz Prezydenta Ukrainy vid 12 sichnia 2015 roku, No. 5/2015 «Pro Stratehiiu staloho rozvytku "Ukraina - 2020"». [Decree of the President of Ukraine dated January 12, 2015. No. 5/2015 “On the Strategy for Sustainable Development “Ukraine - 2020”]. Retrieved from: https://zakon.rada.gov.ua/laws/show/5/2015.

Ukaz Prezydenta Ukrainy, No. 203/2020 «Pro Richnu natsionalnu prohramu pid ehidoiu Komisii Ukraina - NATO na 2020 rik» [Decree of the President of Ukraine No. 203/2020 "On the Annual National Program under the auspices of the NATOUkraine Commission for 2020"]. Retrieved from: https://www.president.gov.ua/ documents/2032020-33861.

Ukaz Prezydenta Ukrainy № 555/215 «Pro rishennia Rady natsionalnoi bezpeky i oborony Ukrainy vid 2 veresnia 2015 roku «Pro novu redaktsiiu Voiennoi doktryny Ukrainy» [Decree of the President of Ukraine, No. 555/215 “On the Decision of the National Defense and Security Council of Ukraine dated September 2, 2015 "On the New Edition of the Military Doctrine of Ukraine"]. Retrieved from: https://zakon. rada.gov.ua/laws/show/555/2015\#Text.

Ukaz Prezydenta Ukrainy, No. 392/2020 «Pro rishennia Rady natsionalnoi bezpeky i oborony Ukrainy vid 14 veresnia 2020 roku «Pro Stratehiiu natsionalnoi bezpeky Ukrainy» [Decree of the President of Ukraine No. 392/2020 “On the Decision of the National Defense and Security Council of Ukraine dated September 14, 2020 "On the National Security Strategy of Ukraine”]. Retrieved from: https://www.president.gov. ua/documents/3922020-35037.

Serdiuk A.M. (2016) Spivpratsia derzhavnoi ta vidomchykh system okhorony zdorovia na osoblyvyi period [Cooperation of state and interagency healthcare systems for special period]. Medychne zabezpechennia antyterorystychnoi operatsii: naukovoorhanizatsiini ta medyko-sotsialni aspekty: zbirnyk naukovykh prats [Medical support of the anti-terrorism operation: scientific-organizational and medical-social aspects: a collection of abstracts]. Kyiv: DP "Priorytety", pp. 27-34.

Shekera, O.H., Stebliuk, V.V., Kyrzhner ,H.D. (2014). Systema medychnoho zabezpechennia obiednanykh zbroinykh syl NATO: Kolonka holovnoho redaktora [Medical 
support system of NATO Allied Forces: Chief Editor's note]. Health and society, nos. 1-2, pp. 105-108.

Tarasov, V., Salkutsan, S.M., Mylchenko, O.M. et al. (2016). Tsyvilno-viiskove spivrobitnytstvo za standartamy NATO: Navch. posib. [Civil military cooperation under NATO standards]. Kyiv: National Defence University of Ukraine named after Ivan Cherniakhovskyi. (in Ukrainian)

The Cabinet of Ministers of Ukraine (2018). Postanova Kabinetu Ministriv Ukrainy vid 31 zhovtnia 2018, No. 910 «Pro zatverdzhennia Voienno-medychnoi doktryny Ukrainy» [Decree of the Cabinet of Ministers of Ukraine as of October 31, 2018, No. 910 "On the Approval of Military Medical Doctrine of Ukraine]. Retrieved from: https://zakon.rada.gov.ua/laws/show/en/910-2018-\%D0\%BF/print.

Zhakhovskyi, V.O. (2014). Derzhavne upravlinnia systemoiu formuvannia kadrovoho potentsialu medychnoi sluzhby zbroinykh syl u konteksti yevropeiskoi ta yevroatlantychnoi intehratsii Ukrainy [State management of the personnel potential creation system of the Medical Service of the Armed Forces of Ukraine within the framework of European and Euro-Atlantic integration of Ukraine] (PhD Thesis): Kyiv: NADU. Retrieved from: http://nadu.kyiv.ua/8/4/doc/aref\%20Sos.pdf. 